\title{
Coffee extracts effectively inhibit the formation of a-chymotrypsin amyloid-like fibrils in aqueous ethanol in vitro
}

\author{
Márta Kotormán $^{1,2} \cdot$ Vanda Andrea Bedő $^{1}$
}

Received: 9 August 2019 / Accepted: 9 March 2020 / Published online: 13 May 2020

(c) The Author(s) 2020

\begin{abstract}
In this study, an in vitro $\alpha$-chymotrypsin aggregation model was used to demonstrate that certain extracts of commercial coffees effectively inhibit protein aggregation in 55\% ethanol at $\mathrm{pH} 7.0$. To detect the anti-amyloidogenic effect of the various coffee extracts, turbidity measurements and Congo red binding assays were performed as well as the determination of the total polyphenol content of the extracts. The greatest fibril formation inhibitory effect was exerted by the Eduscho coffee extract, which contained also the most of the phenolic compounds. The Eduscho coffee extract inhibited the fibrillation of the $\alpha$-chymotrypsin dose dependently. Coffee extracts are effective anti-aggregation agents, and their beneficial effects strongly correlate with the total phenolic content.
\end{abstract}

Keywords Amyloid fibrils $\cdot \alpha$-Chymotrypsin $\cdot$ Coffee $\cdot$ Congo red $\cdot$ Polyphenols

\section{Introduction}

Protein conversion from their soluble state into well-structured amyloid fibrils is considered to cause a wide range of neurodegenerative diseases and systemic amyloidosis (Chiti and Dobson 2009). Stabilization of the structure of proteins can be accomplished by immobilization (Kotormán et al. 1986), chemical modification (Kotormán et al. 2009) or addition of additive molecules (Kotormán et al. 2003). In plants, the lack of amyloid formation, unlike in humans, suggests that plants probably possess special mechanisms to fight against undesirable protein misfolding (Kalhor and Ashrafianm 2017). Plants contain a number of aggregation inhibitors, including many polyphenolic compounds (Mohammad-Beigi et al. 2019; Laczkó-Zöld et al. 2018; Colica et al. 2018; Rose et al. 2018). To date, significant efforts have been made to discover new, effective molecules to avoid protein misfolding to prevent these diseases (Sohail

Márta Kotormán

kotorman@expbio.bio.u-szeged.hu

1 Department of Biochemistry and Molecular Biology, Faculty of Science and Informatics, University of Szeged, Közép fasor 52, Szeged 6726, Hungary

2 Present Address: Department of Biochemistry and Molecular Biology, University of Szeged, Közép fasor 52, Szeged 6726, Hungary et al. 2018; Kasi and Kotormán, 2019). Nontoxic natural agents are very efficient in therapy (Maliszewska et al. 2016; Sharma and Ghosh 2019). Coffee is one of the most widespread beverages in the world. Coffee consumption reduces the risk of many chronic illnesses such as type 2 diabetes, coronary heart disease, several types of cancer as well as Parkinson's disease. Increased coffee consumption during aging reduces the risk of Alzheimer's disease (Ludwig et al. 2014; Cao et al. 2011). Coffee is rich in various polyphenols, especially phenolic acids (chlorogenic acids, caffeic acid, ferulic acid), quinic acid and quercetin (Colombo and Papetti 2019). The aromatic rings of polyphenols can competitively interact with aromatic residues in amyloidogenic proteins and prevent the $\pi-\pi$ interaction. They also block the selfassembly process of the proteins. The phenolic hydroxyls of polyphenolic compounds probably inhibit amyloid fibril formation by binding to the hydrophobic residues in amyloidogenic proteins (Kotormán et al. 2018; Cheng et al. 2013). It was found that the position of hydroxyl groups on the aromatic ring was the most important determining factor for their anti-amyloidogenic properties, but their number was insignificant (Porzoor et al. 2015; Kotorman et al. 2017). The experimental results confirm that chlorogenic and caffeic acids significantly inhibited the human islet amyloid polypeptide oligomerization (Cheng et al. 2011). Ferulic acid effectively inhibited the fibril formation of amyloid $\beta$-protein (Yamada et al. 2015). It was found that quinic acid 
is a very strong anti-fibrillating agent (Shamsi et al. 2016). Small organic, hydrophobic molecules can easily cross the blood-brain barrier; quercetin is such a compound (Vus et al. 2019; Sandeep and Nandini 2017). Quercetin potently inhibited $A \beta$ oligomerization. By stabilizing the smaller oligomer species formed before fibrillation, it inhibited the formation of $\alpha$-synuclein fibrils (Mancini et al. 2018). The caffeine component of coffee can reduce the risk of many neurodegenerative diseases (Madeira et al. 2017), and it has an amyloid inhibitory activity on aggregation of $A \beta 16-22$ peptides (Sharma and Paul 2016). According to the experimental results, caffeine interacts with the aromatic part of the peptide, and thereby inhibits the formation of $\beta$-sheets (Sharma et al. 2016). An alkaloid of coffee beans trigonelline has a neuroprotective effect (Fahanik-Babaei et al. 2019). Pyrocatechol resulting from chlorogenic acid during roasting reduces $\mathrm{A} \beta$ production (Fukuyama et al. 2018).

Previously, we had investigated the anti-amyloidogenic effects of different coffee extracts using a PMS-trypsin model protein (Kasi et al. 2018). We supposed that we would get similar results with the $\alpha$-chymotrypsin model protein too, since its three-dimensional structure is similar to trypsin. However, in the case of $\alpha$-chymotrypsin, there is no need for chemical modification of the enzyme to avoid autolysis, since autolysis at $\mathrm{pH} 7.0$ in the presence of 55\% ethanol is negligible. It was hoped that the results to be obtained in our present study would confirm that the anti-amyloidogenic effect of polyphenolic compounds in coffee extracts is not limited to a single protein such as trypsin but also to other proteins such as $\alpha$-chymotrypsin. The presence of a mild solvent causes an increase in the $\beta$-sheet conformation in proteins (Furkan et al. 2016). According to our earlier study, $\alpha$-chymotrypsin forms amyloid-like fibrils in 55\% ethanol at pH 7.0 after 24-h incubation (Simon et al. 2012).

\section{Materials and methods}

\section{Materials}

Three times crystallized, lyophilized $\alpha$-chymotrypsin (EC 3.4.21.1) from bovine pancreas was the product of SigmaAldrich Ltd. (Budapest, Hungary). Folin-Ciocalteu's phenol reagent was purchased from Merck Ltd. (Darmstadt, Germany). The ground, roasted coffees were bought from commercial sources: Eduscho Wiener Extra and Tchibo Family were bought from Tchibo Budapest Ltd. (Budaörs, Hungary), Bravos Classic from Mocca Negra Co. (Szentendre, Hungary), Douwe Egberts Omnia Classic and Karaván from Douwe Egberts Hungary Co. (Budapest, Hungary), Jacobs Merido Aroma from Modelez Hungária Ltd. (Budapest, Hungary), Kenya Kiandi, Panama arabica and Brasil Santos from Latin Negyed Ltd. (Szeged, Hungary). All other reagents and buffer components used were of analytical grade.

\section{Preparation of water-soluble coffee extracts}

Three grams of each coffee was weighed and added to $22.5 \mathrm{ml}$ of hot water and then boiled three times. Samples were cooled to room temperature and centrifuged for $1 \mathrm{~min}$ at 13,000 rpm. The supernatant was diluted with distilled water as needed prior to the measurements.

\section{Turbidity measurements}

Turbidity measurements were carried out on a Cecil CE-5501 UV-Vis spectrophotometer using a quartz cuvette with a $1 \mathrm{~cm}$ path length. The turbidity measurements were performed by measuring the absorption of the samples at $350 \mathrm{~nm}$ after $24-\mathrm{h}$ incubation at $24{ }^{\circ} \mathrm{C}$, in $55 \%$ ethanol at $\mathrm{pH}$ 7.0. Respective blank corrections had been made prior to all experiments. The $\alpha$-chymotrypsin concentration was $0.15 \mathrm{mg} / \mathrm{ml}$ in these measurements.

\section{Determination of total phenolic content}

The total phenolic contents of the coffee extracts were measured according to Waterhouse with Folin-Ciocalteu reagent, measuring the absorption of the resulting blue color at $765 \mathrm{~nm}$ against the reagent blank (Waterhouse 2002). The calibration line was made from 0 to $50 \mathrm{mg} / \mathrm{l}$ gallic acid. Finally, all polyphenol contents were given in $\mathrm{mg}$ gallic acid equivalent/l (mg GAE/l) unit.

\section{Congo red (CR) binding assay}

A redshift in the absorption maximum of CR (disodium3,3'[[1,1-biphenyl]-4,4'-diylbis(azo)]bis(4-amino-naphthalin-1-sulphonate)) absorption spectrum indicates the presence of increased cross $\beta$-sheet-rich structure (Alam et al. 2016). The CR absorption spectra were recorded on a Hitachi U 2000 spectrophotometer. For this experiment, $200 \mu \mathrm{l}(0.15 \mathrm{mg} / \mathrm{ml})$ aliquots of the 1-day-aged protein samples were withdrawn and mixed with $800 \mu \mathrm{l}$ of CR solution containing $150 \mathrm{mM} \mathrm{NaCl}$ in $5 \mathrm{mM}$ phosphate buffer at $\mathrm{pH}$ 7.0. The samples had been incubated for $15 \mathrm{~min}$ at $24{ }^{\circ} \mathrm{C}$ before the measurements. The absorption spectra of the resulting samples were recorded in a 1-cm-path length cuvette. Difference spectra were constructed by subtraction of the spectra of $\alpha$-chymotrypsin alone and CR alone from the spectra of $\alpha$-chymotrypsin $+\mathrm{CR}$. 


\section{Statistical analysis}

All experimental data were represented as mean \pm standard error of the mean (SEM) from the average of three independent measurements. Significance was determined by one-way analysis of variance (ANOVA), followed by Tukey's multiple comparison test.

\section{Results}

\section{a-Chymotrypsin aggregation}

The $\alpha$-chymotrypsin samples were incubated in the presence and absence of different coffee extracts diluted 50 times in $55 \%$ ethanol at $\mathrm{pH} 7.0$ for $24 \mathrm{~h}$. The aggregation propensity of $\alpha$-chymotrypsin samples in the absence and presence of various coffee extracts was monitored via turbidity measurements. The sample without the coffee extract showed maximum absorption value at $350 \mathrm{~nm}$, whereas the presence of the coffee extracts showed a marked decrease in it. As with the PMS-trypsin model protein, Eduscho coffee extract was the most effective aggregation inhibitor with $\alpha$-chymotrypsin too. The percentage of inhibition was calculated from turbidity measurements: The relative absorbance of the coffee extract at $350 \mathrm{~nm}$ was subtracted from 1 and multiplied by 100. We also wanted to know if the total polyphenol contents of the coffee extracts changed in 2 years. Thus, we also re-measured the total amounts of polyphenol in the coffee extracts we had used. The total phenolic contents of the tested coffee extracts varied from $3717 \pm 337.2$ to $7146 \pm 412.6 \mathrm{mg} \mathrm{GAE} / \mathrm{l}$. According to our results, the total polyphenol contents of the samples decreased to $81.3 \%$ after 2 years of storage as an average. The largest amount of total phenolic content was detected in the Eduscho coffee extract; at the same time, it had the strongest inhibitory effect on aggregation too (Fig. 1). Based on our data, the correlation coefficient between the total phenolic content and the percentage of inhibition is 0.782 . At 50 -fold dilution, the Eduscho coffee extract caused $99.91 \%$ inhibition of protein aggregation.

At different concentrations of the Eduscho coffee extract, the relative absorption at $350 \mathrm{~nm}$ was also measured. Turbidity intensities were in inverse relation to the Eduscho coffee concentrations. The Eduscho coffee extract showed concentration-dependent inhibitory effect on $\alpha$-chymotrypsin aggregation (Fig. 2).

\section{CR binding assay}

The inhibitory effect of the Eduscho coffee extract on the protein fibrillation was also monitored by CR binding assay. A slight redshift of the absorption maximum of $\mathrm{CR}$ was

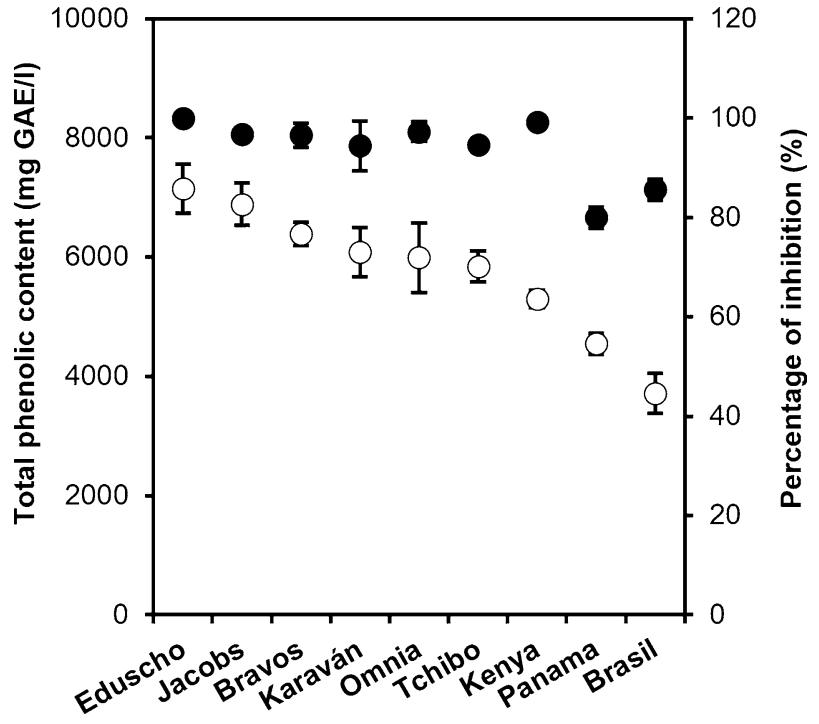

Fig. 1 Change in the percentage of inhibition in 55\% ethanol (filled circle) with the total phenolic content (open circle). Coffee extracts were diluted 50 times in distilled water. Protein concentration was $0.15 \mathrm{mg} / \mathrm{ml}$. All data were presented as mean \pm standard error of the mean (SEM) from three independent measurements

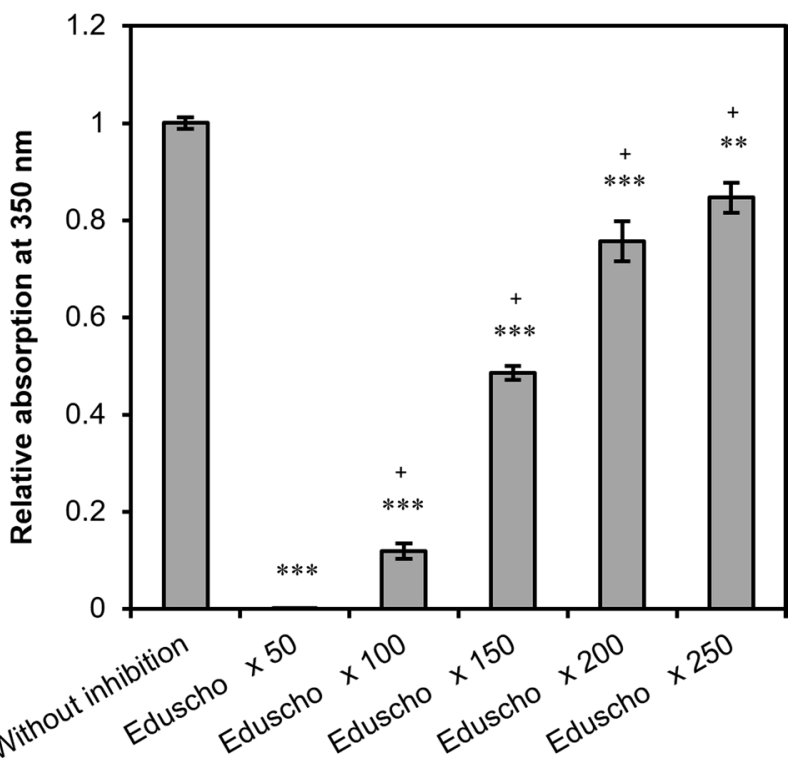

Fig. 2 Turbidity measurements in the absence and presence of different concentration of Eduscho coffee extracts by recording the absorption at $350 \mathrm{~nm}$ at $0.15 \mathrm{mg} / \mathrm{ml} \alpha$-chymotrypsin concentration in $55 \%$ ethanol at $\mathrm{pH}$ 7.0. Each bar represents the average of at least three independent measurements. All data are presented as mean \pm standard error of the mean (SEM). Significance was defined as $* * * P<00.001$ and $* * P<0.01$ compared to the sample without Eduscho coffee extract, and the significance was defined as $+P<0.05$ compared to the previous dilution using one-way analysis of variance (ANOVA), followed by Tukey's multiple comparison test 


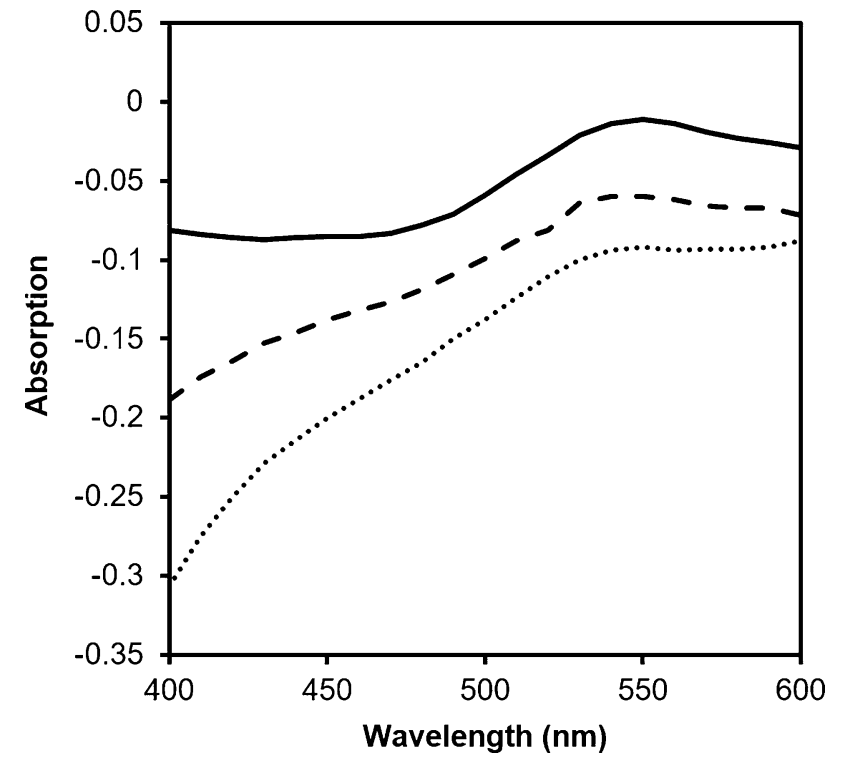

Fig. $3 \mathrm{CR}$ absorption difference spectra of $\alpha$-chymotrypsin in the absence (solid line) and presence of the Eduscho coffee extract diluted 50 times (dotted line) and 100 times (dashed line)

observed in the presence of $\alpha$-chymotrypsin. The maximum spectral difference in the absence and presence of Eduscho coffee extract was observed at $550 \mathrm{~nm}$, but in the presence of the Eduscho coffee extract the value of the maximum was lower than without it (Fig. 3). CR binding experiments suggested that the Eduscho coffee extract was capable of inhibiting $\alpha$-chymotrypsin fibril formation in a concentration-dependent manner.

Our results demonstrated that the Eduscho extract had a preventive effect on protein aggregation. It was capable of inhibiting $\alpha$-chymotrypsin amyloid-like fibril formation effectively in vitro, and the process was concentration dependent. According to our experiments, the Eduscho coffee extract can serve as a valuable source of beneficial phenolic compounds for the prevention of protein aggregation.

\section{Discussion}

Numerous studies have shown that plant biophenols reduce fibril formation and toxicity (Omar 2017). Many of the compounds present in coffee have neuroprotective effects. Caffeic acid and chlorogenic acid prevent neurodegeneration. Coffee consumption reduces the risk of developing Parkinson's and Alzheimer's diseases. It is possible to use a food-based promising therapeutic strategy against neurodegenerative diseases (Miyazaki et al. 2019; Mancini et al. 2018). Amyloid growth detection is generally performed by measuring the turbidity of the solution (Zhao et al. 2016). The decrease in turbidity measured in the presence of the inhibitory agent indicates the efficacy of an inhibitor (Ali et al. 2019). CR amyloid-specific dye binds mainly to $\beta$-sheet conformation of amyloid fibrils (Klunk et al. 1989). The formation of amyloid-like fibrils was tested by measuring the increase and redshift in absorption of CR in the range between 400 and $600 \mathrm{~nm}$ (Fazili et al. 2016; Kotormán et al. 2015). CR binding assay has been extensively utilized to study the anti-fibrillation activity of various inhibitors (Awasthi and Saraswathi 2016).

\section{Conclusion for future biology}

Our experimental findings support the fact that moderate coffee consumption helps reduce amyloid fibril formation thus decreasing the chances for the development of various amyloidoses.

Acknowledgements Open access funding provided by University of Szeged (SZTE).

Authors' contributions The experimental work was carried out by $\mathrm{VAB}$; the manuscript was written by MK.

Funding This work was supported by Project EFOP-3.6.1-16-2016-00008.

Data accessibility The data sets supporting this article have been uploaded as part of the Supplementary Material.

\section{Compliance with ethical standards}

Conflict of interest The authors declare no competing interests.

Open Access This article is licensed under a Creative Commons Attribution 4.0 International License, which permits use, sharing, adaptation, distribution and reproduction in any medium or format, as long as you give appropriate credit to the original author(s) and the source, provide a link to the Creative Commons licence, and indicate if changes were made. The images or other third party material in this article are included in the article's Creative Commons licence, unless indicated otherwise in a credit line to the material. If material is not included in the article's Creative Commons licence and your intended use is not permitted by statutory regulation or exceeds the permitted use, you will need to obtain permission directly from the copyright holder. To view a copy of this licence, visit http://creativecommons.org/licenses/by/4.0/.

\section{References}

Alam P, Chaturvedi SK, Siddiqi MK, Rajpoot RK, Ajmal MR, Zaman M, Khan RH (2016) Vitamin k3 inhibits protein aggregation: implication in the treatment of amyloid diseases. Sci Rep 6:26759

Ali MS, Al-Lohedan HA, Tariq M, Farah MA, Altaf M, Wabaidur SM, Shakeel Iqubal SM, Tabassum S, Abdullah MMS (2019) Modulation of amyloid fibril formation of plasma protein by saffron 
constituent "safranal": spectroscopic and imaging analyses. Int J Biol Macromol 127:529-535

Awasthi S, Saraswathi NT (2016) Vanillin restrains non-enzymatic glycation and aggregation of albumin by chemical chaperone like function. Int J Biol Macromol 87:1-6

Cao C, Wang L, Lin X, Mamcarz M, Zhang C, Bai G, Nong J, Sussman S, Arendash G (2011) Caffeine synergizes with another coffee component to increase plasma GCSF: linkage to cognitive benefits in Alzheimer's mice. J Alzheimers Dis 25:323-335

Cheng BA, Liu XR, Gong H, Huang LQ, Chen H, Zhang X, Li CZ, Yang MY, Ma BJ, Jiao LH, Zheng L, Huan K (2011) Coffee components inhibit amyloid formation of human islet amyloid polypeptide in vitro: possible link between coffee consumption and diabetes mellitus. J Agric Food Chem 59:13147-13155

Cheng B, Gong H, Xiao H, Petersen RB, Zheng L, Huang K (2013) Inhibiting toxic aggregation of amyloidogenic proteins: a therapeutic strategy for protein misfolding diseases. Biochim Biophys Acta 1830:4860-4871

Chiti F, Dobson CM (2009) Amyloid formation by globular proteins under native conditions. Nat Chem Biol 5:15-22

Colica C, Milanović M, Milić N, Aiello V, De Lorenzo A, Abenavoli L (2018) A systematic review on natural antioxidant properties of resveratrol. Nat Prod Commun 13:1195-1203

Colombo R, Papetti A (2019) An outlook on the role of decaffeinated coffee in neurodegenerative diseases. Crit Rev Food Sci Nutr. https://doi.org/10.1080/10408398.2018.1550384

Fahanik-Babaei J, Baluchnejadmojarad T, Nikbakht F, Roghani M (2019) Trigonelline protects hippocampus against intracerebral $\mathrm{A} \beta(1-40)$ as a model of Alzheimer's disease in the rat: insights into underlying mechanisms. Metab Brain Dis 34:191-201

Fazili NA, Bhat IA, Bhat WF, Naeem A (2016) Anti-fibrillation propensity of a flavonoid baicalein against the fibrils of hen egg white lysozyme: potential therapeutics for lysozyme amyloidosis. J Biomol Struct Dyn 34:2102-2114

Fukuyama K, Kakio S, Nakazawa Y, Kobata K, Funakoshi-Tago M, Suzuki T, Tamura H (2018) Roasted coffee reduces $\beta$-amyloid production by increasing proteasomal $\beta$-secretase degradation in human neuroblastoma SH-SY5Y cells. Mol Nutr Food Res 62:e1800238

Furkan M, Rizvi A, Afsar M, Ajmal MR, Khan RH, Naeem A (2016) In vitro elucidation of the folding intermediates and aggregate formation of hemoglobin induced by acetonitrile: a multispectroscopic approach. Protein Pept Lett 23:884-891

Kalhor HR, Ashrafianm H (2017) Identification of an aspidospermine derivative from borage extract as an anti-amyloid compound: a possible link between protein aggregation and antimalarial drugs. Phytochemistry 140:134-140

Kasi PB, Kotormán M (2019) Avocado juice prevents the formation of trypsin amyloid-like fibrils in aqueous ethanol. Nat Prod Commun 14:1934578X1985141

Kasi PB, Borics A, Molnár K, László L, Kotormán M (2018) Eduscho coffee extract effectively inhibits the formation of amyloidlike fibrils by trypsin in aqueous ethanol. Nat Prod Commun 13:1695-1698

Klunk WE, Pettegrew JW, Abraham DJ (1989) Quantitative evaluation of congo red binding to amyloid-like proteins with a betapleated sheet conformation. J Histochem Cytochem 37:1273-1281

Kotorman M, Kasi PB, Halasz L, Borics A (2017) Inhibition of amyloid-like fibril formation of trypsin by red wines. Protein Pept Lett 24:466-470

Kotormán M, Simon ML, Szajáni B, Boross L (1986) Immobilization of lactate dehydrogenase on polyacrylamide beads. Biotechnol Appl Biochem 8:53-59

Kotormán M, Laczkó I, Szabó A, Simon LM (2003) Effects of $\mathrm{Ca}^{2+}$ on catalytic activity and conformation of trypsin and $\alpha$-chymotrypsin in aqueous ethanol. Biochem Biophys Res Commun 304:18-21
Kotormán M, Cseri A, Laczkó I, Simon LM (2009) Stabilization of $\alpha$-chymotrypsin in water organic solvent mixtures by chemical modification with organic acid anhydrides. J Mol Catal B Enzym 59:153-157

Kotormán M, Simon ML, Borics A, Szabó MR, Szabó K, Szögi T, Fülöp L (2015) Amyloid-like Fibril Formation by Trypsin in Aqueous Ethanol Inhibition of Fibrillation by PEG. Protein Pept Lett 22:1104-1110

Kotormán M, Varga A, Kasi PB, Nemcsók J (2018) Inhibition of the formation of amyloid-like fibrils with spices, especially cloves. Acta Biol Hung 69:385-394

Laczkó-Zöld E, Komlósi A, Ülkei T, Fogarasi E, Croitoru M, Fülöp I, Domokos E, Ştefănescu R, Varga E (2018) Extractability of polyphenols from blackcurrant, redcurrant and gooseberry and their antioxidantactivity. Acta Biol Hung 69:156-169

Ludwig IA, Clifford MN, Lean ME, Ashihara H, Crozier A (2014) Coffee: biochemistry and potential impact on health. Food Funct 5:1695-1717

Madeira MH, Boia R, Ambrosio AF, Santiago AR (2017) Having a coffee break: the impact of caffeine consumption on microgliamediated inflammation in neurodegenerative diseases. Med Inflamm 2017:4761081

Maliszewska M, Maciążek-Jurczyk M, Pożycka J, Szkudlarek A, Chudzik M, Sułkowska A (2016) Fluorometric investigation on the binding of letrozole and resveratrol with serum albumin. Protein Pept Lett 23:867-877

Mancini RS, Wang Y, Weaver DF (2018) Phenylindanes in brewed coffee inhibit amyloid-beta and tau aggregation. Front Neurosci $12: 735$

Miyazaki I, Isooka N, Wada K, Kikuoka R, Kitamura Y, Asanuma M (2019) Effects of enteric environmental modification by coffee components on neurodegeneration in rotenone-treated mice. Cells 8:pii: E221

Mohammad-Beigi H, Kjaer L, Eskandari H, Aliakbari F, Christiansen G, Ruvo G, Ward JL, Otzen DE (2019) A possible connection between plant longevity and the absence of protein fibrillation: basis for identifying aggregation inhibitors in plants. Front. Plant Sci 10:148

Omar SH (2017) Biophenols pharmacology against the amyloidogenic activity in Alzheimer's disease. Biomed Pharmacother 89:396-413

Porzoor A, Alford B, Hügel H, Grando D, Caine J, Macreadie I (2015) Anti-amyloidogenic properties of some phenolic compounds. Biomolecules 5:505-527

Rose K, Wan C, Thomas A, Seeram NP, Ma H (2018) Phenolic compounds isolated and identified from Amla (Phyllanthus emblica) juice powder and their antioxidant and neuroprotective activities. Nat Prod Commun 13:1309-1311

Sandeep MS, Nandini CD (2017) Influence of quercetin, naringenin and berberine on glucose transporters and insulin signalling molecules in brain of streptozotocin-induced diabetic rats. Biomed Pharmacother 94:605-611

Shamsi A, Ahmed A, Bano B (2016) Glyoxal induced structural transition of buffalo kidney cystatin to molten globule and aggregates: anti-fibrillation potency of quinic acid. IUBMB Life 68:156-166

Sharma V, Ghosh KS (2019) Inhibition of amyloid fibrillation by small molecules and nanomaterials: strategic development of pharmaceuticals against amyloidosis. Protein Pept Lett 26:315-323

Sharma B, Paul S (2016) Action of caffeine as an amyloid inhibitor in the aggregation of A $\beta 16-22$ peptides. J Phys Chem B 120:9019-9033

Sharma B, Kalita S, Paul A, Mandal B, Paul S (2016) The role of caffeine as an inhibitor in the aggregation of amyloid forming peptides: a unified molecular dynamics simulation and experimental study. RSC Adv 6:78548-78558 
Simon LM, Laczkó I, Demcsák A, Tóth D, Kotormán M, Fülöp L (2012) The formation of amyloid-like fibrils of $\alpha$-chymotrypsin in different aqueous organic solvents. Protein Pept Lett 19:544-550

Sohail A, Bhat WF, Bhat SA, Furkan M, Shah A, Bano B (2018) Investigating the preventive effects of baicalin and gallocatechin against glyoxal-induced cystatin aggregation. J Biomol Struct Dyn 36:3791-3802

Vus K, Girych M, Trusova V, Gorbenko G, Kurutos A, Vasilev A, Gadjev N, Deligeorgiev T (2019) Cyanine dyes derived inhibition of insulin fibrillization. J Mol Liq 276:541-552
Waterhouse AL (2002) Determination of total phenolics. In: Wrolstad $\mathrm{R}$ (ed) Current protocols in food analytical chemistry. Wiley, New York, pp I1.1.1-I1.1.8

Yamada M, Ono K, Hamaguchi T, Noguchi-Shinohara M (2015) Natural phenolic compounds as therapeutic and preventive agents for cerebral amyloidosis. Adv Exp Med Biol 863:79-94

Zhao R, So M, Maat H, Ray NJ, Arisaka F, Goto Y, Carver JA, Hall D (2016) Measurement of amyloid formation by turbidity assay-seeing through the cloud. Biophys Rev 8:445-471 